\title{
KAJIAN HUKUM TERHADAP PENGELOLAAN ASET DAERAH
}

\section{Hasan Basri ${ }^{1}$}

Email: hasanbasri@unimal.ac.id

Dosen Fakultas Hukum Universitas Malikussaleh

\begin{abstract}
.Regional property (BMD) can be obtained from apbd or other legitimate acquisitions and become regional wealth. State wealth in ministries / institutions / local governments become the authority and responsibility of ministries / institutions / local governments. But in the course of regional asset management sometimes also poses problems. Whereas wellmanaged regional assets will have a strategic role in supporting regional budget revenues. Bmd utilization applies to BMD located in the user of the goods, as well as who manages the goods. The existence of provisions, ensuring the process of utilization of BMD can run in an orderly, directed, fair, accountable, to realize efficient, effective, and optimal bmd management therefore regional asset management needs to be established and implementation based on the provisions of applicable laws and regulations. There should be a new mindset in the management of state assets so that not only just to record also list its fair value in the government financial report (LKPP), there should also be new thinking on how to optimize the management of state assets to be more optimal. The purpose of this writing is to review from the legal aspects regarding the management of regional assets. The research method used in this writing is done with literature studies. The approach used in this study is the approach of legislation and conceptual approach. The data source in this paper uses secondary legal material in the form of all publications about which are not official documents.
\end{abstract}

Keywords: Regional Assets, Asset Management, the rule of law 


\section{PENDAHULUAN}

Konsep negara kesejahteraan menurut Bagir Manan dalam Lukman Hakim menyebutkan bahwa negara atau pemerintah tidak semata-mata sebagai penjaga keamanan atau ketertiban masyarakat, tetapi memikul tanggung jawab utama untuk mewujudkan keadilan sosial, kesejahteraan umum, dan sebesar-besarnya kemakmuran rakyat. (Lukman Hakim, 2011) Sejalan dengan pendapat Bagir Manan, menurut Sjahran Basah, berkaitan dengan negara kesejahteraan tersebut, maka tujuan pemerintah tidak semata-mata di bidang pemerintahan saja, melainkan harus melaksanakan kesejahteraan sosial dalam rangka mencapai tujuan negara melalui pembangunan nasional. (Basah, Sjachran, 1989).

Negara Indonesia menunjukkan keinginan untuk membentuk negara kesejahteraan tersebut sebagaimana diamanatkan dalam Pembukaan Undang-Undang Dasar 1945, yaitu: "Membentuk suatu pemerintah negara Indonesia yang melindungi segenap bangsa Indonesia dan seluruh tumpah darah Indonesia, dan untuk memajukan kesejahteraan umum, mencerdaskan kehidupan bangsa, serta ikut melaksanakan ketertiban dunia yang berdasarkan kemerdekaan, perdamaian abadi dan keadilan sosial". (Hartono, Sunaryati, 1991).

Dalam mencapai tujuan yang diamanatkan Pembukaan UndangUndang Dasar 1945 tersebut, maka dilakukanlah pembangunan nasional di dalam segala bidang kehidupan baik fisik maupun pembangunan non fisik. Dalam rangka penyelenggaraan pemerintahan negara dan pembangunan nasional untuk mencapai masyarakat adil, makmur, dan merata berdasarkan Pancasila dan Undang-undang Dasar 1945, maka Pasal 1 UUD 1945 menetapkan bahwa : "Negara Indonesia adalah negara kesatuan yang berbentuk Republik".

Di dalam mencapai tujuan tersebut, maka penyelenggaraan pemerintahan negara membagi Negara Kesatuan Republik Indonesia atas daerah-daerah provinsi, dan daerah provinsi terdiri atas daerah-daerah kabupaten dan kota. Tiap-tiap daerah tersebut mempunyai hak dan kewajiban mengatur dan mengurus sendiri urusan pemerintahannya untuk meningkatkan efisiensi dan efektivitas penyelenggaraan pemerintahan dan pelayanan kepada masyarakat.

$$
\text { Berlakunya Undang-undang }
$$

Nomor 23 Tahun 2014 tentang Pemerintahan Daerah dan Undangundang nomor 33 Tahun 2004 Tentang 
Perimbangan Keuangan Antara

Pemerintah Pusat dan Daerah memberikan kesempatan yang terbuka bagi daerah agar membangun dan mengembangkan daerah sesuai dengan kebutuhan dan prioritasnya masingmasing. Di keluarkannya undangundang ini memberikan konsekuensi logis bagi masing-masing daerah untuk bertanggung jawab atas pengalokasian dana yang dimiliki dengan cara yang efesien dan efektif, khususnya dalam peningkatan kesejahteraan dan pelayanan umum kepada masyarakat. (Aras Aira, 2015)

Salah satu kunci dari keberhasilan pengelolaan ekonomi daerah adalah manajemen aset. Pentingnya manajemen aset secara tepat dan berdayaguna, dengan didasari prinsip pengelolaan yang efisien dan efektif, diharapkan akan memberi kekuatan terhadap kemampuan pemerintah dalam membiayai pembangunan daerahnya yang tercermin dalam Pendapatan Asli Daerah (PAD). Pemerintah daerah dapat menciptakan sumber pendapatan dengan cara melakukan langkah strategis untuk mengoptimalkan aset milik pemerintah daerah yang saat ini dikategorikan masih belum optimal serta mengevaluasi ketidakefisienan dalam hal pengelolaan aset daerah. (Aras Aira, 2015)
Aset daerah merupakan sumberdaya penting bagi pemerintah daerah sebagai penopang utama pendapatan asli daerah. Oleh karena itu, penting bagi pemerintah daerah untuk dapat melakukan manajemen aset secara memadai. Dalam manajemen aset, pemerintah daerah harus menggunakan pertimbangan aspek perencanaan kebutuhan dan penganggaran, pengadaan, penerimaan, penyimpanan dan penyaluran, penggunaan, penatausahaan, pemanfaatan atau penggunaan, pengamanan dan pemeliharaan, penilaian, penghapusan, pemindahtanganan, pembinaan, pengawasan dan pengendalian, pembiayaan dan tuntutan ganti rugi agar aset daerah mampu memberikan kontribusi optimal bagi pemerintah daerah yang bersangkutan sehingga arah pembangunan di Bidang Pengelolaan Aset Daerah dapat terintegrasi dan terprogram dengan baik. (Aprilia, 2018)

Dalam kerangka otonomi daerah, peranan manajemen aset sangat vital karena dalam pengelolaan aset Pemerintah Daerah diperlukan perencanaan yang matang mulai dari rencana pengadaan, pemanfaatan, sampai dengan penghapusan. Pembuatan perencanaan pengelolaan asetpemerintah daerahini tidak dapat dilaksanakan dengan baik sebelum aset tersebut 
diketahui nilai wajarnya sehingga dapat dilakukan optimalisasi terhadap pengelolaan aset Pemerintah daerah. Dengan mengetahui nilai wajar dari aset Pemerintah daerah, maka kasuskasus transaksi tukar guling antara pemerintah daerah dengan pihak lain yang seringkali merugikan pihak pemerintah daerah dapat diminimalkan karena terjadi pertukaran berdasarkan nilai yang wajar dan dapat dipertanggungjawabkan. (Shabrina, 2014)

Namun demikian, pemberian otonomi daerah tidak berarti permasalahan bangsa akan selesai dengan sendirinya. Bertambahnya urusan yang menjadi kewenangan daerah sebagai konsekuensi dari otonomi daerah menimbulkan pengaruh bertambahnya volume urusan terutama berkenaan dengan pengurusan atau pengelolaan aset/kekayaan daerah. Oleh karena itu, otonomi daerah tersebut harus diikuti dengan serangkaian reformasi pemerintah daerah. Dimensi reformasi pemerintahan daerah tersebut tidak saja sekadar perubahan struktur organisasi pemerintahan daerah, akan tetapi mencakup berbagai instrumen yang diperlukan untuk mendukung berjalannya lembaga-lembaga daerah tersebut secara ekonomis, efisien, efektif, transparan, dan akuntabel, salah satunya penataan mengenai pengelolaan aset daerah.

Maka berdasarkan latar belakang diatas menarik untuk dikaji lebih lanjut mengenai pengelolaan aset daerah dalam perspektif hukum supaya tidak ada persoalan dikemudian hari bagi pemerintah daerah dalam penataan aset daerah. Penataan tersebut berusaha untuk mengefesiensi dalam hal pengelolaan aset yang ada di daerah. Tujuannya adalah adalah agar pelaksanaannya dan penggunaannya lebih terarah, transparan, akuntabel dan bertanggungjawab dalam pengelolaan barang milik negara.

\section{METODE PENELITIAN}

Metode penelitian yang
digunakan dalam penulisan ini
dilakukan dengan studi literatur. Tipe
penelitiannya adalah penelitian hukum
(legal research). Untuk memperkuat analisis, dilakukan juga pengumpulan bahan-bahan melalui penelaahan dokumen, pengamatan (observasi). Pengertian penelitian hukum (legal research) dalam hal ini adalah penelitian yang dilakukan dengan mengkaji dan menganalisa substansi peraturan perundang-undangan atas pokok permasalahan atau isu hukum dalam konsistensinya dengan asas-asas hukum, 
teori hukum termasuk pendapat ahli. (Marzuki, Mahmud, 2017)

Pendekatan yang digunakan dalam penelitian ini adalah pendekatan perundang-undangan dilakukan dengan menelaah semua undang-undang dan semua regulasi yang bersangkutan dengan peningkatan perekonomian dan kesejahteraan masyarakat di daerah. Serta digunakan juga pendekatan konseptual (conceptual approach) yang beranjak dari pandangan-pandangan dan doktrin-doktrin yang berkembang di dalam ilmu hukum. akan menemukan ide-ide yang melahirkan: pengertianpengertian hukum, konsep-konsep hukum, dan asas-asas hukum yang relevan dengan isu yang dihadapi.

Sumber data dalam penelitiannya ini menggunakan bahan hukum sekunder berupa semua publikasi tentang yang bukan merupakan dokumen-dokumen resmi. Publikasi tentang hukum meliputi buku-buku teks, kamus-kamus hukum, jurnal-jurnal hukum. Bahan hukum sekunder terutama adalah buku teks karena buku teks berisi mengenai prinsip-prinsip dasar ilmu hukum dan pandanganpandangan klasik para sarjana hukum.(Dewata, 2010).

Teknik pengumpulan data yang akan digunakan dalam penulisan ini dilakukan dengan cara studi kepustakaan (library research). Studi kepustakaan dilakukan untuk mengumpulkan data sekunder melalui pengkajian terhadap, peraturan perundang-undangan, literatur-literatur, tulisan-tulisan pakar hukum, dokumen resmi, publikasi dan hasil penelitian yang berkaitan dengan penulisan ini.

\section{PEMBAHASAN}

\section{Kajian Teoritis Mengenai Aset Daerah}

Aset/barang milik daerah adalah semua kekayaan daerah baik yang dibeli atau diperoleh atas beban Anggaran Pendapatan dan Belanja Daerah maupun yang berasal dari perolehan lain yang sah baik yang bergerak maupun yang tidak bergerak beserta bagian-bagiannya atau pun yang merupakan satuan tertentu yang dapat dinilai, dihitung, diukur, atau ditimbang termasuk hewan dan tumbuh-tumbuhan kecuali uang dan surat-surat berharga lainnya. (Soleh, 2010)

Secara sederhana pengelolaan kekayaan (aset) daerah meliputi tiga fungsi utama, yaitu : (1) Adanya perencanaan yang tepat; Pelaksanaan/pemanfaatan secara efisien dan efektif; dan (3) Pengawasan (monitoring). (Soleh, 2010) 
Namun demikian, hal lain yang

tidak kalah pentingnya untuk diperhatikan dari ketiga fungsi yang telah disebutkan di atas adalah berkenaan dengan upaya optimalisasi pengelolaan atau pemanfaataan kekayaan daerah. Untuk itu, diperlukan strategi yang tepat dalam pemanfaatan aset daerah. Sasaran strategis yang harus dicapai dalam kebijakan pengelolaan / pemanfaatan aset daerah antara lain : (1) Terwujudnya ketertiban administrasi mengenai kekayaan daerah baik menyangkut inventarisasi tanah dan bangunan, sertifikasi kekayaan daerah, penghapusan dan penjualan aset daerah, sistem pelaporan kegiatan tukar menukar, hibah, dan ruislag; (2) Terciptanya efisiensi dan efektifitas pembangunan aset daerah;

Pengamanan aset daerah; dan (4) Tersedianya data informasi yang akurat mengenai jumlah kekayaan daerah. (Soleh, 2010)

Salah satu optimalisasi barang daerah/aset daerah yang dapat dilakukan agar tidak membebani anggaran pendapatan dan belanja daerah, bahkan meningkatkan PAD yaitu melalui: perjanjian sewa menyewa, kerjasama pemanfaatan, Bangun Guna Serah (Build Operate and Transfer/BOT); dan Bangun Serah Guna (Build Transfer Operate). Terhadap pemanfaatan aset daerah tersebut dikenakan retribusi daerah sebagai pembayaran atas jasa yang disediakan pemerintah dengan tujuan untuk memperoleh keuntungan yang layak sesuai dengan harga pasar. Pengenaan retribusi atas pemanfaatan kekayaan daerah merupakan perwujudan kegotong royongan masyarakat untuk ikut serta dalam melaksanakan pembangunan di daerah, sehingga tujuan otonomi daerah untuk meningkatkan kesejahteraan masyarakat dapat terwujud.

Namun demikian, perlu disadari bahwa mengelola aset daerah jangan seperti menangani harta warisan nenek moyang yang dapat dilakukan sehendaknya sendiri. Aset daerah merupakan titipan generasi mendatang yang membutuhkan profesionalisasi dan political will yang kokoh. Tidak dapat dipungkiri lagi bahwa manajemen aset termasuk aset pemerintah pusat dan daerah merupakan bidang profesi atau keahlian tersendiri. Sayangnya, pada saat ini belum berkembang dengan baik di lingkungan pemerintahan maupun di satuan kerja atau instansi.

Manajemen aset itu terbagi menjadi lima tahapan kerja yang satu sama lainnya saling berkaitan dan terintegrasi. Tahap yang pertama adalah Inventarisasi Aset. Terdiri atas dua aspek yaitu inventarisasi fisik dan 
yuridis atau legal. Aspek fisik terdiri atas bentuk, luas, lokasi, volume/jumlah, jenis, alamat dan lain-lain. Kemudian, yang dimaksud aspek yuridis adalah status penguasaan, masalah legal yang dimiliki, batas akhir penguasaan dan lain-lain. Proses kerja yang dilakukan dalam tahapan pertama adalah pendataan, kodifikasi atau labelling, pengelompokan dan pembukuan. (Haryanto, 2019)

Tahapan kedua adalah Legal Audit, merupakan satu lingkup kerja manajemen aset yang berupa inventarisasi status penguasaan aset, sistem dan prosedur penguasaan atau pengalihan aset, identifikasi dan mencari solusi atas permasalahan legal. Juga strategi untuk memecahkan berbagai permasalahan legal yang terkait dengan penguasaan ataupun pengalihan aset. (Haryanto, 2019)

Tahapan

Ketiga adalah Penilaian Aset. Merupakan satu proses kerja untuk melakukan penilaian atas aset yang dikuasai. Biasanya ini dikerjakan oleh konsultan independen. Hasil dari nilai aset tersebut akan dapat dimanfaatkan untuk mengetahui nilai kekayaan maupun informasi untuk penetapan harga bagi aset yang ingin dijual maupun untuk disewakan, dimanfaatkan, maupun dikerjasamakan dengan pihak ketiga.
Tahapan keempat adalah Optimalisasi Aset. Merupakan proses kerja dalam manajemen aset yang bertujuan untuk mengoptimalkan (potensi fisik, lokasi, nilai, jumlah/volume, legal dan ekonomi) yang terkandung dalam aset tersebut. Dalam tahapan ini, aset-aset yang dikuasaipemerintah daerahdiidentifikasi dan dikelompokan atas aset yang memiliki potensi dan tidak memiliki potensi. Aset yang memiliki potensi dapat dikelompokan berdasarkan sektorsektor unggulan yang menjadi tumpuan dalam strategi pengembangan ekonomi daerah, baik dalam jangka pendek, menengah maupun jangka panjang. Tentunya kriteria untuk menentukan hal tersebut harus terukur dan transparan. Sedangkan aset yang tidak dapat dioptimalkan, harus dicari faktor penyebabnya. Apakah faktor permasalahan legal, fisik, nilai ekonomi yang rendah ataupun faktor lainnya. Hasil akhir dari tahapan ini adalah rekomendasi yang berupa sasaran, strategi dan program untuk mengoptimalkan aset yang dikuasai. (Antoh, 2017)

Tahapan yang kelima adalah Pengembangan Sistem Informasi Manajemen Aset sebagai wahana untuk pengawasan dan pengendalian aset. Melalui wahana tersebut transparansi 
dalam pengelolaan aset dapat terjamin, sehingga setiap penanganan terhadap suatu aset dapat termonitor secara jelas. Mulai dari lingkup penanganan hingga siapa yang bertanggung jawab menanganinya. (Arie, 2011)

Pakar manajemen aset Doli D. Siregar menyatakan bahwa filosofi dari manajemen aset adalah "Optimizing the utilization of assets in terms of service benefit and financial return", yang mengandung pengertian bahwa pengelolaan aset membutuhkan minimalisasi biaya kepemilikan (minimize cost of ownership), memaksimalkan ketersediaan aset (maximize asset availability) dan memaksimalkan penggunaan aset (maximize asset utilization). Selain memahami filosofinya, pengelola aset daerah harus memahami secara benar pengertian mengenai Barang Milik Daerah versi yang terbaru. Sesuai dengan Peraturan Menteri Dalam Negeri No.19 Tahun 2016 Tentang Pedoman Pengelolaan Barang Milik Daerah. Prinsip dasar pemanfaatan barang daerah adalah tidak membebani APBD dari segi pemeliharaan dan penyerobotan oleh pihak lain, dan menciptakan sumber PAD yang signifikan. (Maharani, 2020)

Menurut Standar Akuntansi Pemerintahan (SAP) aset adalah sumber daya ekonomi yang dikuasai dan/atau dimiliki oleh pemerintah sebagai akibat dari peristiwa masa lalu dan dari mana manfaat ekonomi dan/atau sosial dimasa depan diharapkan dapat diperoleh, baik oleh pemerintah maupun masyarakat, serta dapat diukur dalam satuan uang, termasuk sumber daya nonkeuangan yang diperlukan untuk penyediaan jasa bagi masyarakat umum dan sumbersumber daya yang dipelihara karena alasan sejarah dan budaya. Salah satu unsur penting dalam rangka penyelenggaraan pemerintahan dan pelayanan masyarakat bahwa aset harus dikelola dengan baik dan benar. (A. Haryanto, 2014)

Untuk mencapai manfaat optimal dari sebuah aset, diperlukan pengelolaan yang baik atas siklus hidup aset tersebut. Pengelolaan ini seringkali disebut dengan life cycle asset management. Pengelolaan siklus hidup aset ini dapat dilakukan baik oleh pihak swasta maupun pemerintah. Aset Daerah ialah semua kekayaan pemerintah daerah, baik yang dimiliki maupun yang dikuasai yang berwujud, baik yang bergerak maupun yang tidak bergerak beserta bagian-bagiannya ataupun yang merupakan satuan tertentu yang dapat dinilai, dihitung, atau ditimbang, termasuk hewan dan tumbuh-tumbuhan. (Karianga, 2017) 
Dengan pengertian tersebut, jelas bahwa cakupannya sangat luas dan merupakan pengertian yang sangat mendasar, sebagaimana pula pengertian yang dianut dalam KUHPerdata, yaitu benda terdiri atas benda berwujud dan tidak berwujud, sebagaimana yang tersurat pula dalam Pasal 499 KUHPerdata bahwa oleh UndangUndang yang diartikan dengan zaken adalah semua benda dan hak yang dapat dijadikan objek hak milik.

Selama beberapa dekade, pengelolaan aset Negara dilakukan berdasarkan kepada peraturan perundang-undangan warisan kolonial Belanda, Indische Comptabiliteitswet (ICW). Pengelolaan aset Negara dilakukan dengan sangat tidak memadai, termasuk tidak mewajibkan adanya pelaporan atas aset. Setelah munculnya paket undang-undang tentang pengelolaan Keuangan Negara, antara lain Undang-Undang nomor 17 tahun 2003 tentang Keuangan Negara, Undang-Undang nomor 1 tahun 2004 tentang Perbendaharaan Negara dan Undang-Undang nomor 15 tahun 2005 tentang Pemeriksaan Pengelolaan dan Tanggungjawab Keuangan Negara, barulah semangat reformasi ikut terasa dalam pengelolaan aset Negara.

$$
\text { Mengingat pentingnya }
$$
manajemen aset bagi pemerintah serta besarnya pengeluaran Negara terkait dengan manajemen aset tersebut, maka sudah menjadi keharusan bagi Pemerintah untuk melakukan pengelolaan aset/barang milik Negara secara professional, efektif dan mengedepankan aspek-aspek ekonomis agar pengeluaran biaya-biaya dapat tepat sasaran, tepat penggunaan, tepat penerapan dan tepat sesuai dengan peraturan perundang-undangan yang berlaku (Wardhani, 2018). Untuk tujuan tersebut pemerintah menerbitkan Peraturan Pemerintah nomor 27 Tahun 2014 tentang Pengelolaan Barang Milik Negara/Daerah yang menjadi 'kitab' bagi semua stakeholder yang terkait dengan aset pemerintah. Selanjutnya, diikuti ketentuan teknisnya yang tertuang dalam Peraturan Menteri Keuangan Nomor 14/PMK.06/2016 Tentang Tatacara Penjualan Barang Milik Negara Berupa Kendaraan Milik Perorangan Dinas Kepada Pegawai Negeri Aparatur Sipil Negara, Anggota Tentara Nasional Indoensia, Anggota Kepolisian Republik Indonesia Tanpa Melalui Lelang.

Aset adalah sumber daya ekonomi yang dikuasai dan/atau dimiliki oleh pemerintah sebagai akibat dari peristiwa masa lalu dan dari mana manfaat ekonomi dan/atau sosial di masa depan diharapkan dapat diperoleh, 
baik oleh pemerintah maupun masyarakat, serta dapat diukur dalam satuan uang, termasuk sumber daya nonkeuangan yang diperlukan untuk penyediaan jasa bagi masyarakat umum dan sumber-sumber daya yang dipelihara karena alasan sejarah dan budaya. Manfaat ekonomi masa depan yang terwujud dalam aset adalah potensi aset tersebut untuk memberikan sumbangan, baik langsung maupun tidak langsung, bagi kegiatan operasional pemerintah, berupa aliran pendapatan atau penghematan belanja bagi pemerintah (Juliani, 2018)

Menurut Peraturan Dalam Negeri Nomor 19 Tahun 2016 tentang Pedoman Pengelolaan Barang Milik Daerah, yang dimaksud barang milik daerah adalah semua barang yang dibeli atau diperoleh atas beban Anggaran Pendapatan dan Belanja Daerah atau perolehan lainnya yang sah meliputi: Barang yang diperoleh dari hibah/sumbangan atau yang sejenis; Barang yang diperoleh sebagai pelaksanaan dari perjanjian/kontrak; Barang yang diperoleh berdasarkan ketentuan undang-undang atau barang yang diperoleh berdasarkan putusan pengadilan yang telah memperoleh kekuatan hukum tetap.

Keuangan dan kekayaan daerah yang terbatas semestinya digunakan secara efisien dan efektif untuk memenuhi kebutuhan masyarakat. Setiap rupiah yang dikeluarkan oleh pemerintah hendaknya memiliki pengaruh terhadap membaiknya kesejahteraan masyarakat. Pemerintah yang diberi amanat untuk menjalankan fungsi dan tugasnya meningkatkan kesejahteraan masyarakat seharusnya menempatkan kepentingan dan kebutuhan masyarakat sebagai kriteria utama dalam mengalokasikan anggaran pemerintah. Pemerintah dibentuk untuk meningkatkan kesejahteraan masyarakat. Karena itu, keberadaan pemerintah harus dapat memberi nilai tambah bagi masyarakat, terutama dalam memenuhi kebutuhan-kebutuhan dasarnya. (Suleman, 2021)

Aset pemerintah harus juga digunakan untuk sebesar-besarnya peningkatan kesejahteraan masyarakat. Selama ini pemahaman pejabat pemerintah tentang aset yang tersedia di daerah cenderung terbatas. Aset cenderung dipahami terbatas pada barang milik pemerintah, sedangkan yang dimaksud dengan aset sebenarnya jauh lebih luas, termasuk tanah, sumberdaya alam, dan aset non-tangible lainnya. Karena terbatasnya pemahaman para pengambil kebijakan tentang aset sering menyebabkan pemanfaatan aset di daerah sering kurang optimal dilihat 
dari kepentingan masyarakat. Banyak aset negara di daerah yang digunakan oleh pihak lain, utamanya sektor dunia usaha, yang manfaatnya lebih banyak dinikmati oleh pelaku usaha daripada masyarakat luas di daerah (Wittwer, 2003)

Untuk itu, penyebarluasan konsep aset yang luas perlu dilakukan dikalangan para penyelenggara pemerintahan daerah. Pengaturan tentang penggunaan aset untuk kepentingan ekonomi dan lainnya perlu dilakukan. Pengaturan tentang pemberdayaan aset mesti harus menempatkan kepentingan masyarakat sebagai pertimbangan utama. Penyelenggara pemerintahan daerah harus dapat memanfaatkan aset-aset negara di daerah untuk meningkatkan kesejahteraan masyarakat.

\section{Kajian Terkait Pelelangan Aset Daerah}

Dalam penjelasan Peraturan Pemerintah Republik Indonesia Nomor 84 Tahun 2014 Tentang Penjualan Barang Milik Negara/Daerah Berupa Kendaraan Perorangan Dinas, Penjualan Kendaraan Perorangan Dinas telah diatur dengan ketentuan sebelumnya yaitu Peraturan Pemerintah Nomor 46 Tahun 1971 tentang Penjualan Kendaraan Perorangan Dinas Milik Negara. Peraturan Pemerintah tersebut didasarkan pada Pasal 14 Indonesische Comptabiliteitswet yang mengatur "Barang-barang bergerak lainnya milik Negara yang penjualannya dianggap perlu untuk kepentingan- kepentingan negara, senantiasa harus dijual dihadapan umum, kecuali dalam hal-hal istimewa, dimana pemerintah telah memberikan kuasa atau perintah, untuk menjualnya di bawah tangan". (Rosyadi, 2019).

Diundangkannya Undang-

Undang Nomor 1 Tahun 2004 tentang Perbendaharaan Negara membawa paradigma baru dalam pengelolaan Barang Milik Negara/Daerah. UndangUndang Nomor 1 Tahun 2004 tentang Perbendaharaan Negara mengamanatkan agar Barang Milik Negara/Daerah wajib dikelola dan ditatausahakan dengan sebaik-baiknya serta digunakan untuk penyelenggaraan tugas dan fungsi pemerintah. Teknis pelaksanaan pengelolaan Barang Milik Negara/Daerah telah diatur dalam Peraturan Pemerintah Nomor 27 Tahun 2014 tentang Pengelolaan Barang Milik Negara/Daerah.

$$
\text { Undang-Undang Nomor } 1
$$

Tahun 2004 tentang Perbendaharaan Negara mensyaratkan Barang Milik Negara/Daerah dijual dengan cara lelang, kecuali dalam hal tertentu yang diatur dalam Peraturan Pemerintah. Agar tercipta kepastian hukum dengan memperhatikan asas penyelenggaraan pemerintahan yang baik, perlu merumuskan Peraturan Pemerintah yang mengatur cara penjualan Barang Milik Negara/Daerah tanpa melalui lelang sebagaimana diamanatkan dalam Pasal 
48 ayat (2) Undang-Undang Nomor 1 Tahun 2004.

Berkenaan dengan hal tersebut di atas dan dalam rangka perwujudan pemberian penghargaan atas pengabdian Pejabat Negara, mantan Pejabat Negara, pegawai ASN, anggota TNI, dan anggota Polri, serta untuk menjawab kondisi dan praktik pengelolaan Barang Milik Negara/Daerah berupa penjualan kendaraan perorangan dinas, maka Peraturan Pemerintah Nomor 46 Tahun 1971 tentang Penjualan Kendaraan Perorangan Dinas Milik Negara tersebut telah diganti.

Ruang lingkup Peraturan Pemerintah ini adalah penjualan Kendaraan Perorangan Dinas yang mengacu pada Undang-Undang Nomor 1 Tahun 2004 tentang Perbendaharaan Negara. Kendaraan Perorangan Dinas dengan karakteristik penggunanya dapat dikelompokkan sebagai Barang Milik Negara/Daerah tertentu, sehingga dikecualikan dari penjualan Barang Milik Negara/Daerah lainnya yang dijual secara lelang sebagaimana diatur dalam Peraturan Pemerintah Nomor 27 Tahun 2014 tentang Pengelolaan Barang Milik Negara/Daerah.

Selain penjualan Barang Milik Negara tertentu sebagaimana diamanatkan dalam Pasal 48 ayat (2) Undang-Undang Nomor 1 Tahun 2004 tentang Perbendaharaan Negara, Peraturan Pemerintah ini juga mengatur tentang Program Kepemilikan Kendaraan bagi Pejabat Negara, pegawai ASN, anggota TNI, dan anggota Polri. Dengan pengaturan ini, diharapkan tercipta kepastian hukum pelaksanaan penyediaan kendaraan bagi Pejabat Negara, mantan Pejabat Negara, pegawai ASN, anggota TNI, dan anggota Polri.

Salah satu aset atau alat pendukung yang sangat penting bagi kelancaran tugas-tugas operasional di luar kantor, yaitu kendaraan dinas. Aset ini sangat berguna untuk mendukung kelancaran pekerjaan. Oleh karena itu, pengelolaan kendaraan dinas di lingkungan pemerintah baik provinsi maupun daerah perlu diselenggarakan. Untuk itu perlu diingat ada beberapa faktor penentu dalam penyelenggaraan Pemerintahan Daerah. Faktor penentunya ada 4 (empat) antara lain adalah faktor manusia (sebagai subyek penggerak faktor dinamis) dalam penyelenggaraan otonomi daerah. Faktor kedua adalah faktor keuangan yang merupakan tulang punggung bagi terselenggaranya aktifitas pemerintahan daerah. Faktor ketiga adalah faktor peralatan yang merupakan sarana pendukung bagi terselenggaranya aktifitas pemerintahan daerah. Faktor 
keempat adalah faktor organisasi dan manajemen. (Martina, 2020)

Pada dasarnya fasilitas aset kendaraan sangat dibutuhkan dalam menunjang kelancaran aktivitas pekerjaan, namun pada kenyataannya seringkali ditemui masalah baik itu kurangnya penyediaan aset kendaraan maupun sudah tersedianya aset kendaraan tetapi tidak didukung oleh proses pemeliharaan yang baik. Asetaset tersebut tidak terpakai efisiensinya sehingga nilai kerusakannya akan semakin parah jika tidak di pergunakan atau tidak diperhatikan pemeliharaannya dengan baik.

Berdasarkan Peraturan Menteri Keuangan Nomor 14/PMK.06/2016 Tentang Tatacara Penjualan Barang Milik Negara Berupa Kendaraan Milik Perorangan Dinas Kepada Pegawai Negeri Aparatur Sipil Negara, Anggota Tentara Nasional Indoensia, Anggota Kepolisian Republik Indonesia Tanpa Melalui Lelang.

Penatausahaan Barang Milik Negara/Daerah meliputi kegiatan pembukuan, Inventarisasi, dan pelaporan. Tertibnya Penatausahaan Barang Milik Negara/Daerah dapat sekaligus mewujudkan pengelolaan Barang Milik Negara/Daerah yang tertib, efektif, dan optimal. Penatausahaan Barang Milik
Negara/Daerah dilaksanakan dengan berpedoman pada kebijakan umum Penatausahan Barang Milik Negara/Daerah yang ditetapkan oleh Menteri Keuangan.

Hasil Penatausahaan Barang Milik Negara/Daerah digunakan dalam rangka penyusunan neraca Pemerintah Pusat/Daerah, Perencanaan Kebutuhan, pengadaan dan pemeliharaan Barang Milik Negara/Daerah yang secara langsung akan menjadi bahan dalam penyusunan rencana kerja dan anggaran Kementerian/Lembaga/ satuan kerja perangkat daerah dan perencanaan Barang Milik Negara/Daerah. Pelaporan Barang Milik Negara/Daerah disusun menurut perkiraan neraca yang terdiri dari aset lancar, aset tetap dan aset lainnya. Aset lancar berupa persediaan, aset tetap berupa tanah, peralatan dan mesin, gedung dan bangunan, jalan irigasi dan jaringan, aset tetap lainnya dan konstruksi dalam pengerjaan. Aset lainnya terdiri dari aset tak berwujud, aset kemitraan dengan pihak ketiga dan aset tetap yang dihentikan dari penggunaan operasional pemerintahan.

\section{Realitas Pengelolaan Aset Daerah}

$$
\text { Kondisi faktual dalam }
$$

pengelolaan aset dapat diberikan gambaran bahwa pelaksanaan inventarisasi aset daerah kurang 
memberikan peningkatan pengelolaan, karena pengklasifikasian barang yang belum optimal. Pemeliharaan aset daerah juga kurang dilakukan secara periodik dan kurangnya perhatian pegawai terhadap aset daerah yang dipakai setiap harinya. Penghapusan aset daerah dalam meningkatkan pengelolaan yang efektif juga masih relatif kurang baik. Hal ini disebabkan kurang optimalnya pendataan barang dari setiap Satuan Kerja Perangkat Daerah. Pengelolaan pengawasan aset daerah juga masih kurang memberikan kontribusi terhadap peningkatan pengelolaan yang efektif, karena pengawasan yang dilakukan belum sepenuhnya secara rutin dilakukan secara langsung dengan mengecek secara langsung dilapangan, sehingga memungkinkan terjadinya penyimpangan terhadap pengelolaan aset daerah yang berakibat pada hilangnya aset daerah. Pada beberapa kasus bahkan terjadi barang yang rusak ringan maupun berat dan pembelian barang tanpa dilakukan pembukuan.

Hal lain yang dapat dikemukakan adalah untuk mengetahui dan mendeskripsikan proses pengelolaan barang milik daerah belum sepenuhnya terlaksana dengan baik. Hal ini meliputi aspek perencanaan kebutuhan dan penganggaran, pengadaan, penerimaan dan penyaluran, penggunaan, penatausahaan, pengamanan dan pemeliharaan, pemanfaatan, penilaian, dan penghapusan barang milik daerah yang kurang sesuai dengan kebutuhan organisasi, sehingga menimbulkan inefisiensi dan kemubaziran.

Dalam Undang-Undang No. 23 Tahun 2014 tentang Pemerintah Daerah sebagaimana telah diubah beberapa kali terakhir dengan Undang-Undang Nomor 9 Tahun 2015 tentang Perubahan Kedua Atas Undang-Undang Nomor 23 Tahun 2014 tentang Pemerintahan Daerah terutama Dalam Paragraf 4 mengenai Pengelolaan Barang Milik Daerah, khususnya Pasal 307 menyebutkan:

$\begin{array}{lrr} & \text { (1) Barang } & \text { milik } \\ \text { Daerah yang } & \text { diperlukan } & \text { untuk } \\ \text { penyelenggaraan } & \text { Urusan } & \\ \text { Pemerintahan } & \text { tidak } & \text { dapat } \\ \text { dipindahtangankan. } & & \end{array}$

(2) Pelaksanaan pengadaan barang milik Daerah dilakukan sesuai dengan kemampuan keuangan dan kebutuhan Daerah berdasarkan prinsip efisiensi, efektivitas, dan transparansi dengan mengutamakan produk dalam negeri sesuai dengan ketentuan peraturan perundangundangan.

(3) Barang milik Daerah yang tidak digunakan untuk penyelenggaraan Urusan Pemerintahan 
dapat dihapus dari daftar barang milik Daerah dengan cara dijual, dipertukarkan, dihibahkan, disertakan sebagai modal Daerah, dan/atau dimusnahkan sesuai dengan ketentuan peraturan perundang-undangan.

(4) Barang milik Daerah sebagaimana dimaksud pada ayat (1) dan ayat (3) tidak dapat dijadikan tanggungan atau digadaikan untuk mendapatkan pinjaman.

Dalam Undang-Undang tentang Pemerintahan Daerah ini, terdapat ketentuan-ketentuan mengenai pembagian urusan Pemerintah Pusat dan pemerintahan daerah. Penyelenggaraan desentralisasi mensyaratkan pembagian urusan pemerintahan antara pemerintah dengan daerah otonom. Pembagian urusan pemerintahan tersebut didasarkan pada pemikiran bahwa selalu terdapat berbagai urusan pemerintahan yang sepenuhnya/tetap menjadi kewenangan pemerintah. Urusan pemerintahan tersebut menyangkut terjaminnya kelangsungan hidup bangsa dan negara secara keseluruhan. Urusan pemerintahan dimaksud meliputi: politik luar negeri, pertahanan, keamanan, moneter, yustisi, dan agama, dan bagian tertentu urusan pemerintah lainnya yang berskala nasional, tidak diserahkan kepada daerah.
Dalam Pasal 2 Peraturan

Menteri Dalam Negeri Nomor 19 Tahun 2016 tentang Pedoman Pengelolaan Barang Milik Daerah menyebutkan bahwa pengelolaan barang milik negara/daerah meliputi perencanaan kebutuhan dan penganggaran, pengadaan, penggunaan, pemanfaatan, pengamanan dan pemeliharaan, penilaian, penghapusan, pemindahtanganan, penatausahaan, pembinaan, pengawasan dan pengendalian.

$$
\text { Selanjutnya dalam Pasal } 3
$$

disebutkan bahwa Barang milik daerah meliputi:

a. barang milik daerah yang dibeli atau diperoleh atas beban APBD; atau

b. barang milik daerah yang berasal dari perolehan lainnya yang sah.

Pasal 4 juga menyatakan:

(1) Barang milik daerah sebagaimana dimaksud dalam Pasal 3 dilarang digadaikan/dijaminkan untuk mendapatkan pinjaman atau diserahkan kepada pihak lain sebagai pembayaran atas tagihan kepada pemerintah daerah.

(2) Barang milik daerah sebagaimana dimaksud dalam Pasal 3 tidak dapat disita sesuai dengan 
ketentuan peraturan perundangundangan.

\section{Pasal 5}

(1) Barang milik daerah yang dibeli atau diperoleh atas beban APBD sebagaimana dimaksud dalam Pasal 3 huruf a, dilengkapi dokumen pengadaan.

(2) barang milik daerah yang berasal dari perolehan lainnya yang sah sebagaimana dimaksud dalam Pasal 3 huruf b, dilengkapi dokumen perolehan.

(3) Barang milik daerah sebagaimana dimaksud pada ayat (1) dan ayat (2) bersifat berwujud maupun tidak berwujud

Dengan perencanaan kebutuhan aset tersebut, pemerintah daerah dapat terhindarkan dari kepemilikan aset yang sesuai dengan kebutuhan sehingga dapat menjaga dan meningkatkan kualitas pelayanan yang diberikan pada masyarakat. Selain faktor perencanaan kebutuhan aset, faktor pengamanan dan pemeliharaan aset juga harus menjadi pertimbangan pemerintah daerah. Dengan pengamanan dan pemeliharaan aset, pemerintah daerah dapat menjaga kepemilikan dan dapat menerima manfaat ekonomis aset dalam rangka usaha pemerintah daerah memberikan pelayanan pada masyarakat. Faktor yang tidak kalah penting dalam pengelolaan aset pemerintah daerah adalah sistem informasi data. Dengan sistem informasi data aset pemerintah daerah yang memadai, pemerintah data dapat lebih mudah dan cepat untuk memperoleh data terkait aset ketika dibutuhkan sewaktu-waktu. Dengan sistem informasi data, pemerintah daerah juga dapat menyusun laporan aset secara lebih handal sehingga dapat memberi informasi yang lebih handal pada pemakai informasi dalam laporan keuangan. (Iskandar, 2011).

Kebijakan dan
pengelolaan aset oleh pimpinan
pemerintah daerah dapat memberi
arahan bagi pelaksanaan pengelolaan
aset pemerintah. Dengan adanya
kebijakan dan strategi pengelolaan aset yang tepat oleh pimpinan pemerintah daetah akan dapat mengoptimalkan manfaat aset bagi pemerintah daerah.

Walaupun sudah banyak kebijakan tentang sistem dan prosedur yang diterbitkan untuk mencegah penyalahgunaan asset negara, namun tampaknya hal itu masih belum cukup. Aset tetap negara merupakan salah satu sektor yang paling strategis dalam pengelolaan keuangan negara. Pada umumnya nilai aset tetap negara paling besar di bandingkan akun lain pada 
laporan keuangan. Selain itu, keberadaannya sangat mempengaruhi kelancaran roda penyelenggaraan pemerintahan dan pembangunan. Oleh karena itu, manajemen aset negara tidak bisa dipandang sebelah mata. Sistem Pengendalian Intern(SPI) atas pengelolaan aset tetap negara harus handal untuk mencegah penyimpangan yang dapat merugikan negara. (Saggaf, 2018)

Garis besar kebijakan tentang pengelolaan aset negara diatur dalam PP Nomor 6 tahun 2006 tentang Pengelolaan Barang Milik Negara/Daerah. Untuk tingkat daerah, peraturan tersebut dijabarkan lebih lanjut dalamPeraturan Menteri Dalam Negeri Nomor 17 tahun 2007 tentang Pengelolaan Barang Daerah. Ketentuanketentuan di atas mengatur secara normatif pengelolaan aset negara dari proses perencanaan kebutuhan hingga pelaporan dan pengawasannya. Aktivitas Pengendalian tersebut disusun agar seluruh proses manajemen aset dapat berjalan berdasarkan asas fungsional, kepastian hukum, transparansi dan keterbukaan, efisiensi, akuntabilitas, dan kepastian nilai. Visi pengelolaan aset negara kedepan adalah menjadi the best state asset management on the world. (Hubaidi, 2021) Tidak sekedar bersifat teknis administratif semata, melainkan sudah bergeser ke arah bagaimana berpikir layaknya seorang manajer aset yang harus mampu merumuskan kebutuhan barangmilik negara secara nasional dengan akurat dan pasti, serta meningkatkan faedah dan nilai dari aset negara tersebut. Tantangan untuk mewujudkan visi tersebut tidaklah ringan, perlu kerja keras dari semua pihak mengingat problematika di seputar pengelolaan aset negara sekarang ini begitu kompleks. Oleh karena itu, pengelolaan aset negara harus ditangani oleh SDM yang profesional dan handal, dan mengerti tata peraturan perundangan yang mengatur aset negara. Penertiban BMN padakementerian/lembaga negara yang sekarang lagi berjalan harus dijadikan momentum bersama untuk menginventarisir dan menata kembali aset negara yang selama ini masih belum tertangani dengan baik, agar penggunaan dan pemanfaatan aset negara sesuai dengan peruntukannya, serta mampu memberikan manfaat yang sebesar-besarnya bagi negaradalam memberikan pelayanan kepada masyarakat.

Mengenai masalah pengelolaan aset daerah berupa tanah, perlu diteliti lebih seksama faktor penyebabnya, apakah peraturan yang adabelum cukup, atau sumber daya manusianya yang belum mampu melaksanakan kegiatan 
pengelolaan, atau barangkali faktor lain, seperti minimnya anggaran yang tersedia. Masalah krusial terutama adalah dalam hal pengadministrasian dan pemanfaatan aset daerah berupa tanah, yang tercermin dengan seringnya terjadi berita tentang permasalahan aset pemerintah daerah yang berupa tanah di berbagai media cetak maupun elektronik, misalnya: adanya sertifikat ganda, penyerobotan, pendudukan illegal, aset hilang, dan lain-lain. (Apriyanto, 2020).

Setiap kerugian negara akibat kelalaian, penyalahgunaan atau pelanggaran hukum atas pengelolaan barang milik negara diselesaikan melalui tuntutan ganti rugi sesuai dengan ketentuan peraturan perundangundangan.

$$
\text { Setiap pihak yang }
$$
mengakibatkan kerugian negara dapat dikenakan sanksi administratif dan/atau sanksi pidana sesuai dengan ketentuan peraturan perundang-undangan. (Rajagukguk, 2006)

Pada dasarnya, fungsi pengawasan dan pengendalian aset daerah ini sudah ada pada tugas pokok dan fungsi pada Satuan Kerja Perangkat Daerah. Untuk menjamin kelancaran penyelenggaraan pengelolaan barang milik daerah secara berdayaguna dan berhasilguna, maka fungsi pembinaan, pengawasan dan pengendalian sangat penting untuk menjamin tertib administrasi pengelolaan barang milik daerah. Peraturan Menteri Dalam Negeri Nomor 17 Tahun 2007 tentang Pedoman Teknis Pengelolaan Barang Milik Daerah, menjelaskan bahwa pengendalian merupakan usaha atau kegiatan untuk menjamin dan mengarahkan agar pekerjaan yang dilaksanakan berjalan sesuai dengan rencana yang telah ditetapkan sedangkan pengawasan merupakan usaha atau kegiatan untuk mengetahui dan menilai kenyataan yang sebenarnya mengenai pelaksanaan tugas dan/atau kegiatan, apakah dilakukan sesuai peraturan perundang-undangan.

\section{KESIMPULAN}

Optimalisasi pengeloalan kekayaan/aset daerah pada saat ini perlu ditingkatkan lagi, banyak aset daerah yang dibiarkan terlantar tanpa perawatan dan pengawasan. Oleh sebab itu pentingnya evaluasi Optimalisasi Pemanfaatan Aset/Barang Milik Daerah dengan cara mengevaluasi secara detail terhadap pemanfaatan aset saat ini (existing use) dengan hal yang sama diluar aset daerah. Misalnya besarnya sewa, tingkat produksi, harga barang dan parameter lainnya. Juga pentingnya evaluasi perbandingan pendapatan dari 
aset atau Return on Asset (ROA). Dari hasil evaluasi terhadap penerimaan dari masing-masing aset tersebut dapat diambil tindakan tegas dan langkah strategis kedepan.

\section{DAFTAR PUSTAKA}

Aira, Aras. "Peran manajemen aset dalam pembangunandaerah." Kutubkhanah 17. 1 (2015): 21-39.

Arie, Siti Sundari, et al. "Laporan Kompendium Hukum Bidang Perbankan." Pusat Penelitian dan Pengembangan Sistem Hukum Nasional Badan Pembinaan Hukum Nasional Kementerian Hukum dan HAM RI, Jakarta (2011): 1-2.

Antoh, Agustina Ester. "Pengaruh Manajemen Aset Dalam Optimalisasi Aset Tetap (Tanah dan Bangunan) Pemerintah Daerah (Studi di Kabupaten Paniai)." Jumabis: Jurnal Manajemen dan Bisnis 1.2 (2017).

Aprilia, Ika, Yusman Syaukat, and A. Faroby Falatehan. "Optimisasi Manajemen Aset Tetap Daerah Dalam Mewujudkan Good Governance Di Pemerintah Provinsi Dki Jakarta." Jurnal Manajemen Pembangunan Daerah 10.2 (2018).

Basah, Sjachran. Eksistensi dan Tolak Ukur Badan Peradilan Administrasi di Indonesia. Alumni, 1989.

Budi Apriyanto, G. D. IMPLEMENTASI PROGRAM SERTIFIKASI ASET DAERAH TERKAIT SEKOLAH YANG BELUM BERSETIFIKAT DI BADAN PENGELOLAAN KEUANGAN ASET DAERAH KABUPATEN JEMBER. Diss.
Universitas Muhammadiyah Jember, 2020.

Dewata, Mukti Fajar Nur, and Yulianto Achmad. "Dualisme Penelitian Hukum Normatif dan Empiris Pustaka Pelajar." (2010).

Hakim, Lukman. "Kewenangan organ negara dalam penyelenggaraan pemerintahan." Jurnal Konstitusi 4.1 (2011).

Hartono, Sunaryati. Politik hukum menuju satu sistem hukum nasional. Alumni, 1991.

Hariyanto, Agus. "Penggunaan Basis Akrual Dalam Akuntansi Pemerintahan Di Indonesia." Dharma Ekonomi 19.36 (2014).

HARYANTO, Haryanto. "Buku: SEJUMPUT PENGGALAN KEUANGAN DAERAH." (2019).

Hubaidi, Hubaidi. "PENERAPAN PRINSIP-PRINSIP GOOD GOVERNANCE DALAM REGULASI DAN PENGELOLAAN BARANG MILIK DAERAH." commercelaw 1.1 (2021).

Iskandar, Ade Dais, Maulana Yusuf, and Rahmawati Rahmawati. STRATEGI MANAJEMEN ASET DAERAH DI KABUPATEN SERANG (STUDI DI DINAS PENGELOLA KEUANGAN DAN ASET DAERAH KABUPATEN SERANG). Diss. Universitas Sultan Ageng Tirtayasa, 2011.

Juliani, Henny. "Aspek Yuridis Transformasi Hukum Keuangan Publik Ke Keuangan Privat Terhadap Pengelolaan Kekayaan Negara Yang Dipisahkan Pada BUMN." Administrative Law and Governance Journal 1.1 (2018): 25-43. 
Karianga, Hendra. Carut-Marut Pengelolaan Keuangan Daerah di Era Otonomi Daerah. Prenada Media, 2017.

Maharani, Rizka Ananda, Bambang Utoyo, and Eko Budi Sulistio. "Manajemen Aset Pemerintah Daerah (Studi Tentang Manajemen Aset Kendaraan Dinas Berdasarkan Permendagri Nomor 19 Tahun 2016 pada Biro Perlengkapan Sekretariat Daerah Provinsi Lampung Tahun 2019)." Administrativa: Jurnal Birokrasi, Kebijakan dan Pelayanan Publik 2.3 (2020): 383-392.

Marzuki, Mahmud. Penelitian Hukum: Edisi Revisi. Prenada Media, 2017.

Martina, Lisa. Penggunaan Mobil Dinas untuk Kepentingan Pribadi dalam Perspektif Milk Al-Daulah dan Hukum Positif (Suatu Penelitian pada Badan Penggelolaan Keuangan Aceh). Diss. UIN AR-RANIRY, 2020.

Rajagukguk, Erman. "Pengertian keuangan negara dan kerugian negara." Makalah disampaikan pada Diskusi Publik "Pengertian Keuangan Negara Dalam Tindak Pidana Korupsi”, Komisi Hukum Nasional Republik Indonesia, Jakarta 26 (2006).

Rosyadi, Julianda. Membongkar Warisan Kolonial di Bidang Hukum Keuangan Negara: Penyusunan Undang-Undang Keuangan Negara 1945-2004. Direktorat Sejarah Direktorat Jenderal Kebudayaan Kementerian Pendidikan dan Kebudayaan Republik Indonesia, 2019.

Shabrina, Kemala Nur. "Efektivitas Pengamanan Aset dalam Mewujudkan Akuntabilitas di Pemerintah Kota Surabaya." Jurnal Kebijakan dan Manajemen Publik 2.1 (2014): 1-9.
Saggaf, Said, Muhammad Mario Said, and Widiawati Said Saggaf. Reformasi Pelayanan Publik di Negara Berkembang. Vol. 1. SAH MEDIA, 2018.

Soleh, Chobib, and Heru Rochmansjah. Pengelolaan keuangan dan aset daerah: sebuah pendekatan struktural menuju tata kelola pemerintahan yang baik. Fokusmedia, 2010.

Suleman, Abdul Rahman, et al. Perekonomian Indonesia. Yayasan Kita Menulis, 2021.

Wardhani, Ratih Kusuma. "Studi Deskriptif tentang Regulatory Accountability Dinas Pengelolaan Bangunan dan Tanah dalam Pengelolaan Aset Tanah Pemerintah Kota Surabaya Pasca Dikeluarkan Kebijakan Reforma Agraria Tahun 2016." Kebijakan dan Manajemen Publik 6.1 (2018): 1-8.

Wittwer, Ernie, Jason Bittner, and Char Kasprzak. "Asset Management and City Government." Mid-Continent

Transportation Research SymposiumIowa State University, Ames. 2003. 